Zlonis, E. J., H. Panci, J. D. Bednar, M. Hamady, and G. J. Niemi. 2017. Habitats and landscapes associated with bird species in a lowland coniferdominated ecosystem. Avian Conservation and Ecology 12(1):7. https://doi.org/10.5751/ACE-00954-120107

Copyright $(C) 2017$ by the author(s). Published here under license by the Resilience Alliance.

Research Paper

\title{
Habitats and landscapes associated with bird species in a lowland conifer-dominated ecosystem
}

\author{
Edmund J. Zlonis ${ }^{1,2}$, Hannah G. Panci ${ }^{3,4,5}$, Josh D. Bednar ${ }^{1,6}$, Maya Hamady ${ }^{7}$ and Gerald J. Niemi ${ }^{1,6}$ \\ ${ }^{1}$ Natural Resources Research Institute, University of Minnesota Duluth, ${ }^{2}$ Wetland Wildlife Population and Research Group, \\ Division of Fish and Wildlife, Minnesota Department of Natural Resources, ${ }^{3}$ Natural Resources Research Institute, ${ }^{4}$ University of \\ Minnesota Duluth, ${ }^{5}$ Great Lakes Indian Fish and Wildlife Commission, ${ }^{6}$ Department of Biology, University of Minnesota Duluth, \\ ${ }^{7}$ Nongame Wildlife Program, Division of Ecological and Water Resources, Minnesota Department of Natural Resources
}

\begin{abstract}
Human-induced effects on lowland conifer forests in hemiboreal regions are increasing because of expanded use of these northern ecosystems for raw materials, energy, and minerals as well as the potential effects of climatic changes. These forests support many breeding bird species across the Holarctic and allow the persistence of several boreal bird species in hemiboreal and even temperate regions. These bird species are of particular conservation concern as shifting patterns northward in forest composition caused by climate change will likely affect their populations. However, effective management and conservation options are limited because the specifics of these species' breeding habitats are not well understood. We modeled and mapped habitat suitability for 11 species of boreal birds that breed in the lowland conifer forests of the Agassiz Lowlands Ecological Subsection in northern Minnesota and are likely to have reduced breeding habitat in the future: Spruce Grouse (Falcipennis canadensis), Black-backed Woodpecker (Picoides arcticus), Olivesided Flycatcher (Contopus cooperi), Yellow-bellied Flycatcher (Empidonax flaviventris), Boreal Chickadee (Poecile hudsonicus), Goldencrowned Kinglet (Regulus satrapa), Ruby-crowned Kinglet (Regulus calendula), Swainson's Thrush (Catharus ustulatus), Connecticut Warbler (Oporornis agilis), Palm Warbler (Setophaga palmarum), and Dark-eyed Junco (Junco hyemalis). Sets of 7 to 16 potential environmental covariates, including both stand-level and landscape attributes, were used to develop individual species models. Within this lowland conifer-dominated ecosystem, we found significant selection for specific forest and landscape characteristics by all but one of these species, with the best models including between one and nine variables. Habitat suitability maps were developed from these models and predictions tested with an independent dataset. Model performance depended on species, correctly predicting 56-96\% of test data. We present a map combining suitability scores for five species of conservation concern that has been used for conservation planning and management opportunities across a broad, lowland forest landscape. We recommend managers utilize the detailed model development and validation framework to address local and regional conservation issues.
\end{abstract}

\section{Milieux et paysages associés avec certaines espèces d'oiseaux dans un écosystème composé de basses terres dominées par les conifères}

RÉSUMÉ. Les impacts provoqués par l'homme sur les forêts conifériennes sises en terrain bas dans les régions hémiboréales augmentent en raison de l'exploitation de plus en plus importante de ces forêts pour les matières premières, l'énergie et les mines, en plus des effets potentiels des changements climatiques. Ces forêts hébergent de nombreuses espèces d'oiseaux holarctiques et assurent la persistance de plusieurs espèces des régions hémiboréale et même tempérée. La conservation de ces espèces d'oiseaux est particulièrement préoccupante considérant que le déplacement de la composition des forêts vers le nord, causé par les changements climatiques, affectera vraisemblablement leurs populations. Les options efficaces de conservation et de gestion sont toutefois limitées étant donné que les besoins en matière de milieux de nidification de ces espèces sont mal compris. Nous avons modélisé et cartographié la qualité des milieux pour 11 espèces d'oiseaux boréaux nichant dans les forêts conifériennes de la sous-section écologique des Basses-terres d'Agassiz dans le nord du Minnesota, et pour lesquelles les milieux de nidification pourraient être réduits dans le futur : Tétras du Canada (Falcipennis canadensis), Pic à dos noir (Picoides arcticus), Moucherolle à côtés olive (Contopus cooperi), Moucherolle à ventre jaune (Empidonax flaviventris), Mésange à tête brune (Poecile hudsonicus), Roitelet à couronne dorée (Regulus satrapa), Roitelet à couronne rubis (Regulus calendula), Grive à dos olive (Catharus ustulatus), Paruline à gorge grise (Oporornis agilis), Paruline à couronne rousse (Setophaga palmarum) et Junco ardoisé (Junco hyemalis). Des ensembles comprenant de 7 à 16 covariables environnementales potentielles, y compris des attributs à l'échelle du peuplement et à celle du paysage, ont été utilisés pour élaborer des modèles uniques à chaque espèce. Dans cet écosystème composé de basses terres dominées par les conifères, nous avons obtenu des sélections significatives de caractéristiques forestières et paysagères spécifiques pour toutes les espèces, sauf une. Les meilleurs modèles incorporaient de une à neuf variables. Des cartes de la qualité de l'habitat ont été élaborées à partir de ces modèles et des prédictions ont été testées au moyen d'un jeu de données indépendant. La performance des modèles dépendait de l'espèce, et les modèles prédisaient correctement de 56 à $96 \%$ des données test. Nous présentons une carte combinant le pointage de la qualité de l'habitat pour 5 espèces de conservation préoccupante; cette carte a 
été utilisée pour planifier la conservation et les occasions d'aménagement sur un vaste paysage forestier de basses terres. Nous recommandons aux gestionnaires de recourir à notre méthode détaillée d'élaboration des modèles et du processus de validation afin de se pencher sur les enjeux de conservation locaux et régionaux.

Key Words: bird conservation; boreal birds; boreal forests; forest management; habitat suitability; hemiboreal; lowland coniferous forest; MaxEnt

\section{INTRODUCTION}

Lowland coniferous forest and forested peatlands, primarily composed of black spruce (Picea mariana) and tamarack (Larix laricina), make up a significant portion of the boreal forest ecosystem (Larsen 1982, Shugart et al. 1992). These forests contain substantial amounts of naturally disturbed virgin forests and are part of one of the last undeveloped forested ecosystems in the world (Heinselman 1981, Hansen et al. 2013). However, climate change (Soja et al. 2007, Johnston 2009) and the use of timber resources (Schmiegelow et al. 2006, Imbeau et al. 2015) affect the functioning of these ecosystems, including the availability of wildlife habitat (e.g., Stralberg et al. 2015).

The effects of climate change and timber extraction may reduce the capacity of these landscapes to support wildlife species, especially bird species that are highly dependent on coniferous forest ecosystems. This is of particular interest at the southern boundary of boreal and peatland habitats in the northern continental USA where populations of some of these species such as Olive-sided Flycatcher (Contopus cooperi), Swainson's Thrush (Catharus ustulatus), and Connecticut Warbler (Oporornis agilis) are declining (Zlonis et al. 2014, Ralston et al. 2015).

Minnesota has the most significant portion of peatlands in the continental United States at nearly 2.5 million ha, much of it forested with black spruce, tamarack, and white cedar (Thuja occidentalis; MNDNR 1984). The coverage of these tree species is predicted to decrease over the next century based on future climate scenarios (Iverson et al. 2008). Annual black spruce and tamarack harvest in Minnesota has increased more than two-fold in the last 30 years (MNDNR 2013), though the current harvest rates are similar to historic harvest rates in the 1950s (Hackett and Dahlman 1997). In addition, growth in these nutrient-poor peatlands is slow (Grigal et al. 1985).

Bird species' habitat associations in lowland coniferous forests are little studied and often lack detail required by management agencies. For example, Pitocchelli et al. (2012) describe Connecticut Warbler breeding habitat as spruce-tamarack bogs and occasionally upland poplar (Populus spp.) forests. More recent work in Minnesota has shown that this species is associated with large patches of lowland conifer adjacent to upland conifer forests (Lapin et al. 2013). However, to better inform forest management and forest planning, additional information regarding specific tree species, age classes, and structural characteristics utilized by species breeding in lowland conifer forests is desirable. To conserve essential habitats or landscapes, an understanding of these relationships must be developed, especially at regional and landscape-level scales that avoid variation inherent in broad distributional habitat selection studies (Franklin 2010).

To address conservation needs in lowland conifer forests of Minnesota, we studied the habitat associations of 11 boreal bird species breeding near the southern limits of their ranges in the
Agassiz Lowlands Ecological Subsection (ALS), where much of Minnesota's peatlands and lowland conifer forests exist in one large complex. We examined the characteristics of these species' breeding habitat by developing and testing a method for modeling habitat suitability across the lowland conifer forests of the ALS. Past research in this region has generally focused on stand-level habitat metrics or cover types, i.e., dominant tree or other vegetative composition, for determining associations for these species (Dawson 1979, Niemi and Hanowski 1984, Warner and Wells 1984, but see Hawrot and Niemi 1996, Crozier and Niemi 2003, Lapin et al. 2013). Here, we used a subset of both standlevel and landscape environmental variables predicted to affect the distribution of species breeding in lowland conifer forests (Table 1).

Table 1. Landscape and forest stand variables included in habitat modeling. Landscape variables were summarized in 200, 500, and $1000 \mathrm{~m}$ buffers surrounding all $30 \mathrm{~m}$ grid cells in the Agassiz Lowlands Subsection. Forest stand variables were derived from the stand where point counts were conducted ( $c$, categorical). Forest stand cover types are described in Table 2. Land cover data come from the Upper Midwest Gap Analysis Program (19911993); lands converted from forest to other types were updated using remotely sensed change data (Hansen et al. 2013).

\begin{tabular}{lll}
\hline \hline Landscape & Landscape (cont'd) & Forest stand \\
\hline Black spruce & Open wet (lowland shrub, sedge & Age (2014) \\
Black spruce/tamarack & meadow) & Area \\
Cedar & Open, nonhabitat & Average DBH \\
Density of streams & Richness of patch types & Basal area \\
Evergreen (spruce, cedar) & Stagnant black spruce & Cover type 1 $c$ \\
Forest (all forest types) & Stagnant lowland conifer & Cover type 2 $c$ \\
Larch beetle mortality & Sedge Meadow & Cover type 3c \\
Lowland conifer (spruce, & Stagnant tamarack & Site index \\
cedar, tamarack) & Tamarack & Trees per acre \\
Lowland Shrub & Upland conifer & \\
Nonforest (all nonforest & Upland deciduous & \\
types) & Upland forest (deciduous, & \\
Number of patches & coniferous) & \\
& Open wet (lowland shrub, sedge & \\
& meadow) & \\
& & \\
\hline
\end{tabular}

We expected that this methodology would be useful to obtain habitat selection information about species that are difficult to detect and for which little is known about specific breeding habitat attributes. Because of this limited knowledge and the unique environmental characteristics of the ALS, we did not propose mechanistically based hypotheses for habitat selection. Rather, we compared the distribution of each species to a null model, thus primarily exploring one statistical hypothesis: the distribution of each of the 11 bird species will differ from a random model. In particular, each species was expected to select for certain types of lowland conifer forest and different scales of landscape variables within lowland conifer forests of the ALS (Table 2). 
Table 2. Landscape and forest stand variables (Table 1) predicted to affect bird species' distributions within the Agassiz Lowland Subsection. The predicted effect of each variable on the species' distribution is indicated as either positive (+) or negative (-) and supporting references are cited.

\begin{tabular}{|c|c|c|}
\hline Species & Predicted variables & References \\
\hline $\begin{array}{l}\text { Spruce Grouse } \\
\text { (Falcipennis canadensis) }\end{array}$ & $\begin{array}{l}(+) \text { Black spruce, }(+) \text { black spruce/tamarack, }(+) \text { upland } \\
\text { conifer, }(-) \text { non-forest }\end{array}$ & Robinson (1969), Pietz and Tester (1982), Anich et al. (2013) \\
\hline $\begin{array}{l}\text { Black-backed Woodpecker } \\
\text { (Picoides arcticus) }\end{array}$ & $\begin{array}{l}(+) \text { Lowland conifer, }(+) \text { age, }(+) \text { average } \mathrm{DBH},(+) \text { larch beetle } \\
\text { mortality }\end{array}$ & $\begin{array}{l}\text { Nappi et al. (2003), Tremblay et al. (2009), Tremblay et al. } \\
\text { (2016) }\end{array}$ \\
\hline $\begin{array}{l}\text { Olive-sided Flycatcher } \\
\text { (Contopus cooperi) }\end{array}$ & $(+)$ Open wet, $(-)$ forest, $(+)$ density of streams & $\begin{array}{l}\text { Altman and Sallabanks (2012), Environment Canada (2015), } \\
\text { Niemi et al. (2016) }\end{array}$ \\
\hline $\begin{array}{l}\text { Yellow-bellied Flycatcher } \\
\text { (Empidonax flaviventris) }\end{array}$ & $(+)$ Lowland conifer, $(+)$ black spruce/tamarack & Gross and Lowther (2011), Niemi et al. (2016) \\
\hline $\begin{array}{l}\text { Boreal Chickadee } \\
\text { (Poecile hudsonicus) }\end{array}$ & $(+)$ Black spruce or evergreen at local scale, $(+)$ basal area & $\begin{array}{l}\text { Erskine (1977), Warner and Wells (1984), Imbeau et al. } \\
\text { (1999), Warren et al. (2005) }\end{array}$ \\
\hline $\begin{array}{l}\text { Golden-crowned Kinglet } \\
\text { (Regulus satrapa) }\end{array}$ & $\begin{array}{l}(+) \text { Evergreen or }(+) \text { upland conifer at local scale, }(+) \text { basal } \\
\text { area, }(+) \text { age }\end{array}$ & $\begin{array}{l}\text { Warner and Wells (1984), Imbeau et al. (1999), Swanson et } \\
\text { al. (2012) }\end{array}$ \\
\hline $\begin{array}{l}\text { Ruby-crowned Kinglet } \\
\text { (Regulus calendula) }\end{array}$ & $(+)$ Black spruce, $(+)$ lowland conifer & $\begin{array}{l}\text { Erskine (1977), Warner and Wells (1984), Swanson et al. } \\
\text { (2008) }\end{array}$ \\
\hline $\begin{array}{l}\text { Swainson's Thrush } \\
\text { (Catharus ustulatus) }\end{array}$ & $(+)$ Cedar, $(+)$ lowland conifer, $(+)$ age, $(+)$ basal area & $\begin{array}{l}\text { Warner and Wells (1984), Thompson et al. (1993), Mack and } \\
\text { Yong (2000), Niemi et al. (2016) }\end{array}$ \\
\hline $\begin{array}{l}\text { Connecticut Warbler } \\
\text { (Oporornis agilis) }\end{array}$ & $\begin{array}{l}(+) \text { Black spruce/tamarack or lowland conifer at landscape } \\
\text { scale, }(+) \text { upland conifer }\end{array}$ & Elder (1991), Pitocchelli et al. (2012), Lapin et al. (2013) \\
\hline $\begin{array}{l}\text { Palm Warbler } \\
\text { (Setophaga palmarum) }\end{array}$ & $\begin{array}{l}(+) \text { Stagnant black spruce, }(+) \text { stagnant tamarack, }(+) \text { Black } \\
\text { spruce/tamarack, }(-) \text { basal area }\end{array}$ & $\begin{array}{l}\text { Niemi and Hanowski (1984), Warner and Wells (1984), } \\
\text { Wilson (2013) }\end{array}$ \\
\hline $\begin{array}{l}\text { Dark-eyed Junco } \\
\text { (Junco hyemalis) }\end{array}$ & $(+)$ Black spruce, $(+)$ evergreen, $(+)$ stagnant lowland conifer & $\begin{array}{l}\text { Erskine (1977), Warner and Wells (1984), Hobson and } \\
\text { Bayne (2000) }\end{array}$ \\
\hline
\end{tabular}

To identify potential areas for conservation, we overlaid models for five species of conservation concern and ranked grid cells by the number of species predicted to have suitable breeding habitat. This study provides a valuable methodological framework for managers seeking to identify breeding habitat and potential conservation areas at regional or landscape scales.

\section{METHODS}

\section{Study area}

The ALS is a large glacial lake basin comprised of open and forested peatland and upland forests in north central Minnesota (approximately $48.4^{\circ} \mathrm{N}, 94.7^{\circ} \mathrm{W}, 15,000 \mathrm{~km}^{2}$; Fig. 1). It is dominated by lowland conifer forests $(26 \%)$, open wet areas including shrublands and sedge fens (34\%), and upland forests (16\%). Agricultural land and large lakes make up the remaining area. Approximately $90 \%$ of the lowland conifer forests are owned and managed by the state of Minnesota. These forests cover nearly $3500 \mathrm{~km}^{2}$ and are classified by the Minnesota Department of Natural Resources (MNDNR) into six major forest cover types depending on tree species and soil moisture gradients: black spruce, tamarack, cedar, stagnant black spruce, stagnant tamarack, and stagnant cedar forests (Table 3).

\section{Avian sampling}

Bird data used to build and test habitat suitability models were from three sources: (1) Point counts conducted in 130 forest stands of the ALS, hereafter referred to as the Agassiz Lowlands Bird Project (ALBP), (2) the Minnesota Breeding Bird Atlas project (MNBBA; http://mnbba.org/), and (3) opportunistic observations gathered during field data collection in 2014. The first dataset constitutes the majority of data used in analyses and is described in detail below. MNBBA data were restricted to the lowland coniferous forests of the ALS and were used to supplement ALBP data for three uncommon species: Spruce Grouse (Falcipennis canadensis), Black-backed Woodpecker (Picoides arcticus), and Olive-sided Flycatcher. Additional opportunistic sightings, often collected when travelling between sampling locations, were used to supplement Spruce Grouse observations. Exact geographic coordinates for these observations were recorded.

Fig. 1. Agassiz Lowland Ecological Subsection, state-owned lowland conifer lands, and associated avian point-count locations. Test sample locations and Minnesota Breeding Bird Atlas counts are omitted.

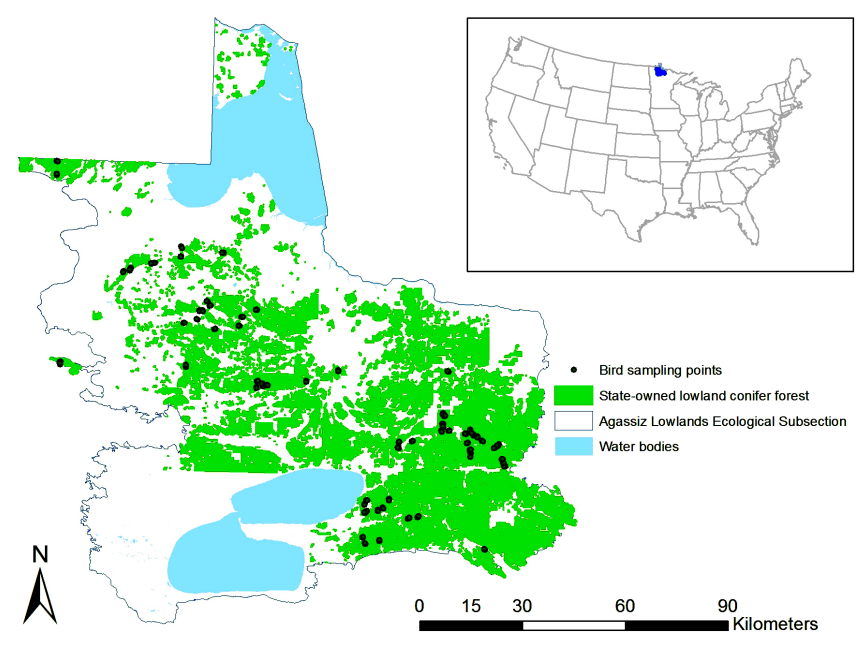


Table 3. Proportion of lowland conifer types within state-owned lowland conifer of the Agassiz Lowland Subsection. Lowland conifer cover types (Type) sampled for birds were combined into three separate variables used in analyses of habitat associations; segregated by tree species and productivity (cover type 1), tree species only (cover type 2), and productivity only (cover type 3 ).

\begin{tabular}{lclll}
\hline \hline Type & $\%$ & Cover type 1 & Cover type 2 & Cover type 3 \\
\hline Black spruce & 22 & Black spruce & Black spruce & Productive \\
Stagnant black & 24 & Stagnant black & Black spruce & Stagnant \\
spruce & & spruce & & \\
Tamarack & 25 & Tamarack & Tamarack & Productive \\
Stagnant tamarack & 13 & Stagnant tamarack & Tamarack & Stagnant \\
Cedar & 7 & Cedar & Cedar & Productive \\
Stagnant cedar & 9 & Stagnant cedar & Cedar & Stagnant \\
\hline
\end{tabular}

The ALBP was designed to identify bird species associated with lowland coniferous forest stand types and management practices in the ALS. Sixty-five stands representing five combinations of productivity, age, and tree species composition were selected for avian sampling. Productivity is highly variable in these lowland systems and is estimated by site index, which is the average height (ft) of a canopy tree with 50 years of growth. The 65 stands represent much of the variability present in lowland conifer forests of the ALS, especially stand types that are considered for timber harvest: (1) black spruce-tamarack, $>90$ years old, productive ( site index $>25$ ), 14 stands; (2) old growth cedar, $>90$ years old, productive and stagnant (site index < 21), 16 stands; (3) black spruce-tamarack, 30-90 years old, productive, 15 stands; (4) black spruce-tamarack, > 30 years old, stagnant, 15 stands; and (5) black spruce-tamarack, regenerating, 0-30 years old, 5 stands. The stands ranged in size from 8 to 191 ha.

Each stand was large enough to accommodate two point count locations separated by a minimum of $250 \mathrm{~m}$. Each point count was 10 minutes and of unlimited distance (Hanowski and Niemi 1995, Etterson et al. 2009). All birds seen or heard within the 10minute interval were recorded and categorized by species, behavior (i.e. singing or calling), the time delay until detection (in minutes), and estimated distance from observer. Surveys were conducted from approximately half hour before sunrise to 4 hours after sunrise in generally good weather conditions (no rain and low wind speed). To capture the breeding window of diverse bird species and identify species not observed on previous counts, each location was sampled five times: twice in early May $(2013,2014)$, twice in early to mid-June $(2013,2014)$, and once in late June to early July (2013). Permanent residents and short-distance migrants were principally breeding during May to early June, respectively. In contrast, most long-distance migrants were not defending territories or beginning to breed until early to mid-June. An additional set of 65 forest stands were selected and sampled in the same manner as above in mid-June to early July 2014. These 65 stands were used to test the models developed from original 65 stands.

\section{Environmental predictor data}

Environmental covariate data were primarily derived from Minnesota's Forest Inventory Monitoring database (FIM) and the Upper Midwest Gap Analysis Program (GAP) land cover database. FIM includes vector polygons of all state-owned forest stands with attributes related to forest structure and composition collected by foresters during stand examinations. GAP land cover is a raster (30-m resolution) that spans all of Minnesota and contains four hierarchical levels of land cover classification, ranging from broad classes such as "forest" (level 1) to more detailed classes such as "stagnant tamarack forest" (level 4). Additional datasets used to derive predictor variables included MNDNR streams, rivers, and ditches (polyline) and MNDNR estimates of eastern larch beetle (Dendroctonus simplex LeConte) induced tamarack mortality (polygon). All datasets were received through MNDNR personnel or downloaded via the MNDNR Data Deli (MNDNR 2012).

We developed two general categories of predictor variables: standlevel forest attributes and landscape variables (Table 1). Standlevel data were derived from the FIM database for stands in which point counts were conducted. These included nine continuous and categorical variables that characterized the stands and were potentially related to the selection of the stands by breeding birds (Tables 1 and 2). Land cover and other landscape variables were derived at three spatial scales $(200,500$, and $1000 \mathrm{~m})$ surrounding each count location. GAP level 4 data were reclassified into 18 land cover types hypothesized to affect bird species breeding in lowland coniferous habitats (Table 1). A variety of metrics of landscape pattern similar to those used in previous modeling efforts for these species were derived from the reclassified GAP data (Hawrot and Niemi 1996, Drolet et al. 1999, Crozier and Niemi 2003, Lapin et al. 2013), but many were highly correlated and only patch richness and number of patches were retained for analysis. Individual patches were defined as contiguous (eight grid cell, nearest neighbor) units of GAP level 4 land cover data. We processed environmental predictor variables in ArcGIS Version 10.2.2 (http://www.esri.com/), Geospatial Modelling Environment Version 0.7.3.0 (Beyer 2012), and FRAGSTATS Version 4 (McGarigal et al. 2012).

\section{Habitat suitability modeling in MaxEnt}

We used MaxEnt (Phillips et al. 2006, Elith et al. 2011) to model correlations between specific species' presence locations and environmental predictor variables. MaxEnt is a machine learning statistical tool that compares well with or outcompetes other modeling techniques (e.g., Elith et al. 2006, Phillips and Dudik 2008, Phillips et al. 2009). It has been shown to be similar to more conventional regression-based approaches used for modeling species environmental correlates (e.g., Renner and Warton 2013, Merow and Silander 2014) and can be applied to a variety of ecological questions depending on how models are calibrated and evaluated (Franklin 2010, Merow et al. 2013).

We used MaxEnt to develop predictive models and maps of boreal bird distributions in the ALS for three specific reasons: (1) MaxEnt is robust to small sample sizes and has outperformed other methods when sample sizes are small (Franklin 2010); (2) assumptions of absences are less relevant for species that were not reliably detected with territorial vocalizations or behaviors, such as the Spruce Grouse, Black-backed Woodpecker, and Boreal Chickadee (Poecile hudsonicus); and (3) MaxEnt models are less sensitive to overprediction than standard GLM methods and have been shown to be more useful for prediction and extrapolation for conservation applications (Jackson et al. 2015). 


\section{Model parameterization}

Transformations used by MaxEnt can create complex models that are difficult to interpret ecologically (Merow et al. 2013); thus, to maintain interpretability, we restricted analysis to linear and quadratic features of environmental predictor variables. Model building and extrapolation were limited to state-owned lowland conifer forests of the ALS. In addition, sampling biases were controlled by restricting the selection of background environmental locations to areas within $500 \mathrm{~m}$ of bird sampling locations; this ensured background locations were equally likely to contain any biases inherent in the sampling design, e.g., proximity to roadways. Five-fold cross-validation was used to validate model predictions. Five different partitions of $80 \%$ of the occurrence data were used to build submodels, while the remaining (and unique) partitions of $20 \%$ of occurrence data were used to test each submodel. The predictions for these five test datasets were then averaged to create the final model. We used MaxEnt's raw output as a relative habitat suitability index (Merow et al. 2013, Merow and Silander 2014) and avoided using MaxEnt's logistic output (Phillips and Dudik 2008, Royle et al. 2012).

\section{Data preparation and Variable reduction}

Bird observations were filtered by species, behavior, distance from observer, and sampling period. We included only observations of territorial male birds observed within $100 \mathrm{~m}$ and within the boundaries of the forest stand. Sex and territoriality could not always be determined for Spruce Grouse, Black-backed Woodpecker, and Boreal Chickadee; all observation types were included for these species. MaxEnt models were generated with each variable and evaluated using the area under the receiver operating curve (area under curve; AUC) as a test of the variables' capacity to separate species occurrence locations from random background locations (Phillips and Dudik 2008). All reported AUC values are averages of the testing data used in crossvalidation. Variables with AUC $<0.55$ (near random discrimination between background and presences) were removed from further analyses. The remaining variables were tested for multicollinearity using ENMTools (Warren et al. 2008, Warren et al. 2010). If variables were highly correlated $(r>0.68)$, the variable with higher AUC for the given species was retained for further analysis.

\section{Model selection and evaluation}

The reduced set of variables ranged from 7 to 16 , depending on species. Starting with the full model for each species, we used backward elimination to develop potential models (Parolo et al. 2008, Bellamy et al. 2013). After each model run the variable that contributed the least to the testing AUC was removed until a single variable model remained. AICc values were calculated using ENMTools. The model with the lowest AICc value was selected as the best model and was used for interpretation and mapping. However, because of potential for overfitting, only single-variable models were considered for species with 10 or fewer samples (Spruce Grouse [10 samples], Black-backed Woodpecker [9], and Olive-sided Flycatcher [9]). Sample sizes of around 10 especially for uncommon species such as these, have been shown to develop useful MaxEnt models (Støa 2014, van Proosdij et al. 2016).

Significance was determined using a restricted-random model approach (Raes and ter Steege 2007; B. Wiestra, personal communication). Random locations equivalent to the number of presence locations for a given species were selected from within state-owned lowland conifer forests of the ALS and then modeled using the environmental predictor variables of the best model. The AUC from the data-driven model was then compared to the distribution of AUC values determined by 999 iterations of random locations. With the maximum probability of a type I error set at 0.05 , the model was deemed significant if its AUC value fell within the top 5\% of random AUC values.

\section{Model validation}

Models were tested with newly acquired data collected in a similar manner as the original training datasets. All test data for Olivesided Flycatcher were acquired from the MNBBA dataset, while the test data for the remaining passerines only included observations from the "new" forest stands sampled in 2014 for ALBP (described above). No reliably georeferenced test samples could be acquired for Spruce Grouse or Black-backed Woodpecker, and only 8 and 10 samples were used for Olive-sided Flycatcher and Boreal Chickadee, respectively. Model predictions were assessed by first developing binary, suitable versus unsuitable, maps for each species. For a given species, the threshold for suitability was set at a level where $90 \%$ of training locations were predicted as suitable (training locations in the lowest $10 \%$ of suitability scores were considered unsuitable; Bellamy et al. 2013). We then calculated the proportion of test samples that met or surpassed that threshold. Statistical significance was determined using chi-square tests, where the number of observed correct predictions was compared with the number of correct predictions expected by chance alone.

Because of the exploratory nature of these models, we included two test species with distinct habitat preferences that are generally well known within the lowland conifer habitat of the ALS. In multiple studies, Palm Warblers (Setophaga palmarum) were exclusively found in stagnant spruce and tamarack forests (Warner and Wells 1984, Wilson 2013; personal observation), often characterized by relatively low tree cover and small diameter trees. In contrast, Swainson's Thrush were primarily observed in cedar stands characterized by dense canopies and open understories (Warner and Wells 1984; personal observation). Indicator species analysis (Dufrêne and Legendre 1997, McCune and Mefford 2006; PC-ORD Version 5) of ALBP data indicated Palm Warbler was a significant indicator of the stagnant black spruce-tamarack forest class and Swainson's Thrush was a significant indicator of the mature cedar forest class. Models and maps developed for these more easily characterized species helped inform the validity and context of models developed for additional species.

\section{Conservation mapping}

Five of the species we modeled are identified by the MNDNR State Wildlife Action Plan as Species of Greatest Conservation Need (SGCN; MNDNR 2016); Spruce Grouse, Black-backed Woodpecker, Olive-sided Flycatcher, Boreal Chickadee, and Connecticut Warbler. Binary suitability maps developed for these species were weighted equally and summed in the ArcGIS Raster Calculator function to create a map indicating the richness of SGCN and potential conservation value of state-owned lowland conifer forests of the ALS.

We tested for spatial autocorrelation in these predictions across the ALS using Global Moran's I. In particular, we were interested 
Fig. 2. Relative habitat suitability index for five boreal bird Species of Greatest Conservation Need breeding in the Agassiz Lowland Subsection of northern Minnesota. Raw MaxEnt output, rescaled to a cumulative index, is presented. Suitability scores should not be compared between species, rather, should be interpreted as a relative scale within each map.
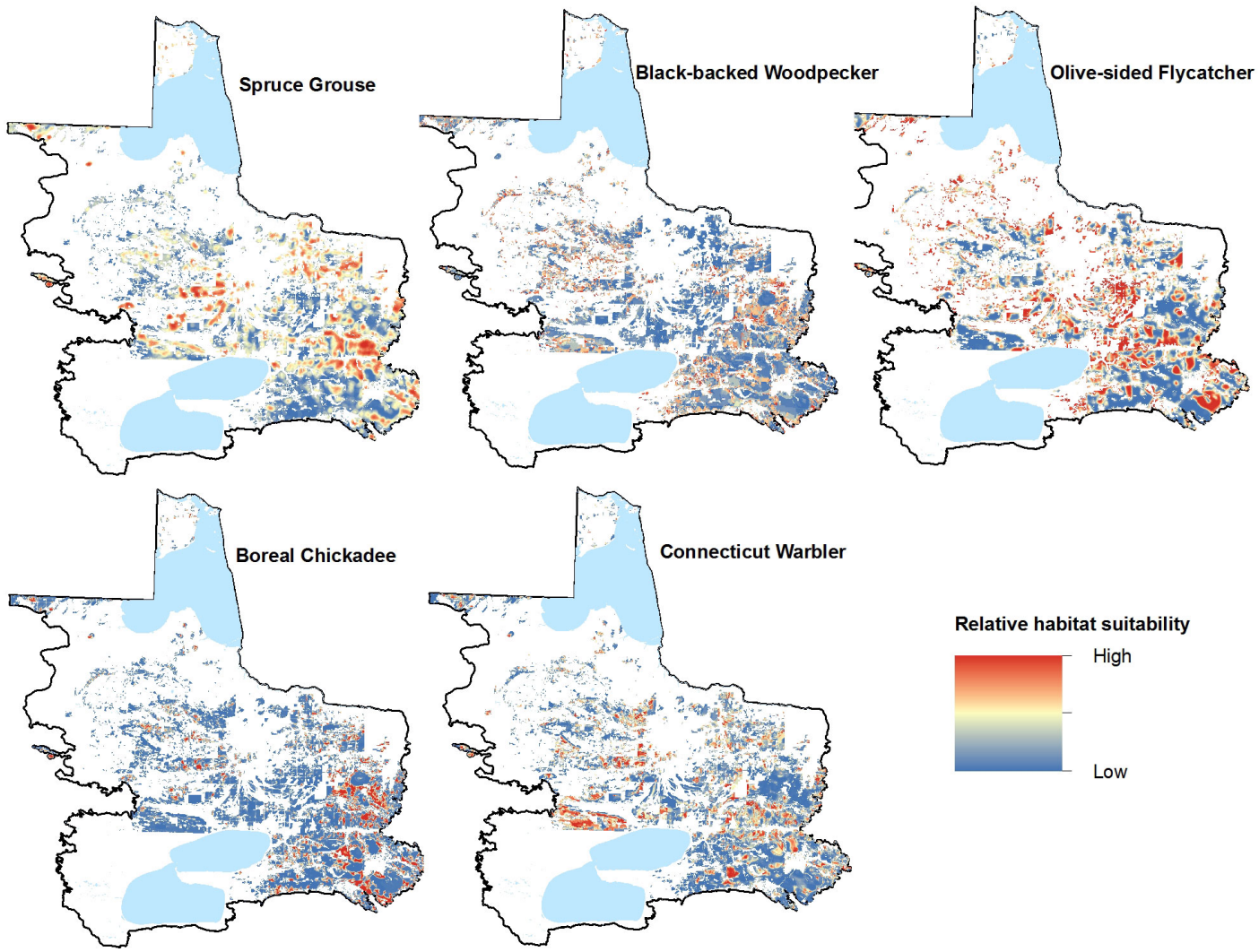

in the scale of spatial clustering of predicted species richness and whether these patterns had any association with the boundary of the ALS, where less lowland conifer was available in the landscape. Similarly, we tested for a correlation between predicted species richness and isolation of patches of lowland conifer forests by correlating the distance of each lowland conifer patch to its nearest neighbor with the predicted species richness of the given patch. For this analysis patches were defined as contiguous areas of lowland conifer with the same predicted species richness.

\section{RESULTS}

Yellow-bellied Flycatcher (Empidonax flaviventris) was the most common species selected for analysis, with territorial males detected within 100 m of the observer at $68 \%$ of ALBP sites. Rubycrowned Kinglet (Regulus calendula; 52\%), Golden-crowned Kinglet (Regulus satrapa; 44\%), Connecticut Warbler (33\%), Dark-eyed Junco (Junco hyemalis; 31\%), Boreal Chickadee (20\%), Palm Warbler (18\%), and Swainson's Thrush (12\%) were observed at intermediate levels. Olive-sided Flycatcher (7\%), Black-backed Woodpecker $(7 \%)$, and Spruce Grouse $(2 \%)$ were uncommon. Presence locations used in modeling ranged from 9 for Blackbacked Woodpecker and Olive-sided Flycatcher to 88 for Yellowbellied Flycatcher (Table 4). Seven opportunistic observations (see Methods) supplemented Spruce Grouse presence locations.

\section{Habitat suitability models}

Through variable reduction we calculated models using 7 to 16 environmental variables per species (Fig. 2, Table 4). Backward selection and subsequent comparison of AICc values produced best models ranging from one to nine variables. Only singlevariable models were developed for uncommon species (10 or fewer observations points): Spruce Grouse, Black-backed Woodpecker, and Olive-sided Flycatcher. Based on comparisons to restricted random models, all species, except Yellow-bellied Flycatcher, were determined to have statistically significant models of habitat selection within the lowland coniferous forest of the ALS, and thus showed nonrandom patterns of habitat association (Table 4).

For the 11 species considered, a land cover variable at the $200-\mathrm{m}$ scale was the best predictor for six species while land cover within $1000 \mathrm{~m}$ was the best predictor for two additional species (Table 4). Stand level variables were predictors in the best models for seven species but were top predictor variables for only three of these seven species.

Black spruce, either individually or combined with one of the other tree species, appeared in the best models for most species (Table 4). No species appeared to be strictly associated with tamarack, and only Swainson's Thrush exclusively selected cedar 
Table 4. Best MaxEnt models for each of 11 species in the Agassiz Lowland Subsection as determined by lowest AICc value. Effects of environmental variables were positive $(+)$, negative $(-)$, categorical (top categories indicated), or quadratic (q). Area under the receiver operator curve (AUC) was used as a metric of model fit and was determined by averaging cross-validated model runs of test samples. Significance was determined by comparing AUC to the distribution of replicated (999) restricted-random MaxEnt models. Note, only single variable models were used for species with 10 or less observations (see methods). See Table 2 for species scientific names.

\begin{tabular}{|c|c|c|c|c|c|}
\hline Species & Variables (effect, $\%$ contribution) & Samples & $\begin{array}{l}\text { Models } \\
\text { compared }\end{array}$ & $\begin{array}{l}\text { AUC } \\
\text { value }\end{array}$ & $\mathrm{P}$ value \\
\hline Spruce Grouse & Black spruce $1000 \mathrm{~m}(+, 100 \%)$ & 10 & & 0.71 & 0.02 \\
\hline Black-backed Woodpecker & Average DBH $(+, 100 \%)$ & 9 & & 0.75 & $<0.01$ \\
\hline Olive-sided Flycatcher & Nonforest $1000 \mathrm{~m}(+, 100 \%)$ & 9 & & 0.72 & 0.03 \\
\hline Yellow-bellied Flycatcher & $\begin{array}{l}\text { Cover type } 1 \text { (stagnant types, } 45 \%) \text {, Patch richness } 500 \mathrm{~m}(\mathrm{q}, 28 \%) \text {, } \\
\text { Stand age }(+, 14 \%) \text {, Stand area (q, } 11 \%) \text {, Site Index (q, 3\%) }\end{array}$ & 88 & 7 & 0.61 & 0.24 \\
\hline Boreal Chickadee & $\begin{array}{l}\text { Evergreen } 200 \mathrm{~m}(+, 86 \%) \text {, Density of streams }(+, 11 \%), \text { Stagnant } \\
\text { tamarack } 500 \mathrm{~m}(-, 3 \%)\end{array}$ & 26 & 14 & 0.83 & $<0.01$ \\
\hline Golden-crowned Kinglet & $\begin{array}{l}\text { Evergreen } 200 \mathrm{~m}(+, 49 \%) \text {, Upland deciduous } 1000 \mathrm{~m}(+, 12 \%) \text {, } \\
\text { Nonforest } 200 \mathrm{~m}(-, 9 \%) \text {, Upland coniferous } 500 \mathrm{~m}(+, 8 \%) \text {, Basal area } \\
(\mathrm{q}, 7 \%) \text {, Cover type } 2(\text { black spruce and cedar, } 6 \%) \text {, Stand Area }(\mathrm{q}, \\
5 \%) \text {, Tamarack } 200 \mathrm{~m}(-, 2 \%) \text {, Number of patches } 200 \mathrm{~m}(-, 1 \%), \\
\text { Stand age (q, } 1 \%)\end{array}$ & 57 & 12 & 0.75 & $<0.01$ \\
\hline Ruby-crowned Kinglet & $\begin{array}{l}\text { Evergreen } 200 \mathrm{~m}(+, 32 \%) \text {, Cover type } 1 \text { (stagnant types, 30\%), Upland } \\
\text { forest } 500 \mathrm{~m}(+, 22 \%) \text {, Nonforest } 200 \mathrm{~m}(-, 16 \%)\end{array}$ & 66 & 13 & 0.71 & $<0.01$ \\
\hline Swainson's Thrush & $\begin{array}{l}\text { Black spruce/tamarack } 200 \mathrm{~m}(-, 30 \%), \text { Stagnant black spruce/ } \\
\text { tamarack } 1000 \mathrm{~m}(-, 28 \%), \text { Site index }(-, 27 \%) \text {, Sedge meadow } 500 \mathrm{~m} \\
(-, 14 \%)\end{array}$ & 15 & 15 & 0.87 & $<0.01$ \\
\hline Connecticut Warbler & $\begin{array}{l}\text { Black spruce/tamarack } 200 \mathrm{~m}(+, 35 \%) \text {, Cover type } 1 \text { (stagnant black } \\
\text { spruce/tamarack, } 20 \%) \text {, Cedar } 1000 \mathrm{~m}(-, 20 \%) \text {, Sedge meadow } 1000 \\
\mathrm{~m}(-, 12 \%) \text {, Basal area }(\mathrm{q}, 11 \%) \text {, Stand age }(\mathrm{q}, 3 \%)\end{array}$ & 43 & 12 & 0.73 & $<0.01$ \\
\hline Palm Warbler & Cover type 1 (stagnant black spruce/tamarack, $100 \%$ ) & 23 & 15 & 0.78 & $<0.01$ \\
\hline Dark-eyed Junco & $\begin{array}{l}\text { Black spruce } 200 \mathrm{~m}(+, 70 \%) \text {, Nonforest } 1000 \mathrm{~m}(+, 16 \%) \text {, Larch } \\
\text { beetle mortality } 500 \mathrm{~m}(-, 9 \%) \text {, Density of streams } 200 \mathrm{~m}(+, 5 \%)\end{array}$ & 40 & 16 & 0.75 & $<0.01$ \\
\hline
\end{tabular}

forests. In addition to tree species composition, general productivity of forest stands, as indicated by cover type 1 (Table 3 ), contributed to best models for four species. Though only a top contributor for Olive-sided Flycatcher, land cover types other than the lowland conifer tree cover (e.g., nonforest, sedge meadow) were included in the best models for six species, often at the $500 \mathrm{~m}$ or $1000 \mathrm{~m}$ landscape scales.

Stand-level variables other than cover type, often structural (e.g., basal area) or a variable related with structural characteristics (e.g., stand age) contributed to models for five species. Only the Blackbacked Woodpecker model relied primarily on one of these variables (the average diameter of trees). However, this may reflect that only 9 stand-level variables were considered as compared with 20 landscape variables (Table 1).

\section{Test species}

The best Palm Warbler model included the categorical Cover Type 1 variable (Table 3 ), with the species responding positively to stands composed of stagnant black spruce and stagnant tamarack forest (Table 4). Swainson's Thrush indicated selection for cedar forests because of negative associations with black spruce and tamarack forests in the best model and positive associations with cedar forests in competing models. The multivariate model had higher AICc support for this species, but two separate single variable models for cedar at the $200 \mathrm{~m}$ scale (+ association) and cover type 2 (+; cedar stands) also had high discriminatory power (average AUC $=0.78$ for cross-validation test samples).

\section{Model validation}

The usefulness of these models for prediction depended on species. Validation varied from a low of $56 \%$ of test samples correctly predicted for Golden-crowned Kinglet to a high of $96 \%$ correctly predicted for Palm Warbler (Table 5). Chi-square tests indicated significant predictive performance for six of nine species examined.

\section{Conservation mapping}

Approximately $29 \%$ of the lowland conifer forests in the ALS were predicted as suitable habitat for three or more Minnesota SGCN (Fig. 3); 6\% of the area was predicted as suitable for four species and $1 \%$ for all five SGCN. Tests of spatial autocorrelation (Global Moran's I) indicated significant spatial autocorrelation in these predictions with a distance threshold of $6.4 \mathrm{~km}$. These clusters were not restricted to specific regions of the ALS and were not negatively associated with the periphery of the study area. In addition, isolation of lowland coniferous forest patches did not appear to influence conservation value; isolation distance and number of SGCN predicted had a Pearson correlation value of -0.04 .

\section{DISCUSSION}

\section{Model evaluation}

A general recommendation is that useful models discriminating background environmental locations from presence locations have an AUC around 0.70 or greater (Araújo et al. 2005). Our models achieved or exceeded this benchmark for all the species included, except for the Yellow-bellied Flycatcher $(\mathrm{AUC}=0.61)$.

The two metrics for evaluating our models, AUC and AICc, were useful in different ways. It is important to recognize that AUC and AICc are not directly related because the calculation of AUC 
Table 5. Test results of predictive ability of MaxEnt models for bird species in the Agassiz Lowlands of Minnesota. Suitability predictions from top models for each species were transformed into binary maps using the top $90 \%$ of model training data and then tested against independently collected datasets. The proportion of test data correctly predicted by each species' top model is reported. In addition, the proportion of suitable lowland conifer habitat (out of all available state-owned lowland conifer) is included. Significance values are results of chi-square tests taking into account the observed and expected number of correct predictions based on the proportion of the study area predicted to be suitable. See Table 2 for species scientific names.

\begin{tabular}{|c|c|c|c|c|}
\hline Species & Test Samples & $\%$ Correctly predicted & $\begin{array}{c}\% \text { Suitable } \\
\text { habitat }\end{array}$ & $\mathrm{P}$ value \\
\hline Olive-sided Flycatcher & 8 & $63 \%$ & $48 \%$ & 0.42 \\
\hline Yellow-bellied Flycatcher & 43 & $88 \%$ & $69 \%$ & $<0.01$ \\
\hline Boreal Chickadee & 10 & $60 \%$ & $37 \%$ & 0.12 \\
\hline Golden-crowned Kinglet & 18 & $56 \%$ & $42 \%$ & 0.24 \\
\hline Ruby-crowned Kinglet & 14 & $93 \%$ & $63 \%$ & 0.02 \\
\hline Swainson's Thrush & 10 & $60 \%$ & $24 \%$ & $<0.01$ \\
\hline Connecticut Warbler & 14 & $71 \%$ & $45 \%$ & $<0.05$ \\
\hline Palm Warbler & 25 & $96 \%$ & $78 \%$ & 0.03 \\
\hline Dark-eyed Junco & 20 & $80 \%$ & $53 \%$ & 0.02 \\
\hline
\end{tabular}

Fig. 3. Number of Species of Greatest Conservation Need predicted to find suitable habitat within lowland conifer forests in the Agassiz Lowland Subsection. Individual species suitability maps for the five species in Figure 2 were transformed into binary maps based on the suitability values of the top $90 \%$ of model training data (see methods). Binary suitability maps were overlaid upon each other to identify the number of species predicted to have suitable habitat in a given area.

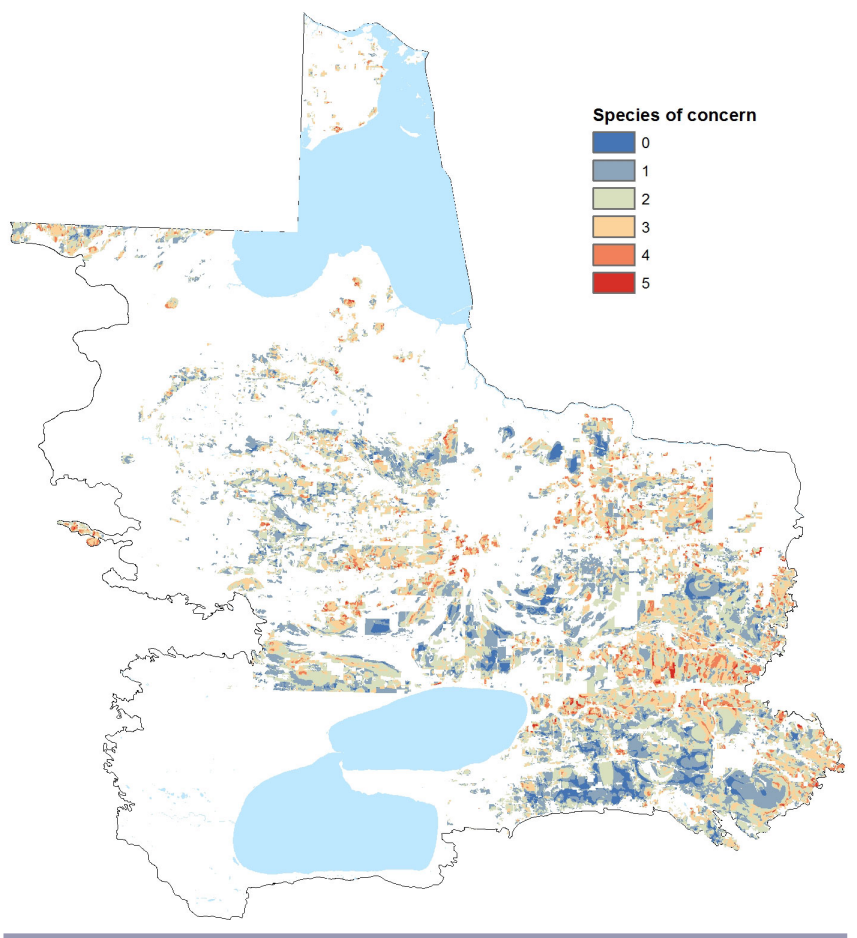

does not include a penalty for increasing parameterization of models. However, we found that AICc-selected models were often the same or very similar to models with the highest test AUC values. Both measures tended to select models of intermediate complexity, though for three species, Ruby-crowned Kinglet, Swainson's Thrush, and Palm Warbler, the AICc-selected models were more parsimonious. There is some evidence that models of intermediate complexity are better able to predict habitat selection and variable contributions (Warren and Seifert 2011).

Predictive ability of habitat models, especially those using remotely sensed geographic information related to land cover and other habitat variables, has been suggested to be moderate at best (Keller and Smith 2014). Yet, MaxEnt models developed here generally performed well, despite relatively small sample sizes for some species. Notable exceptions were for Olive-sided Flycatcher, Boreal Chickadee, and Golden-crowned Kinglet. Few test data were available for the former two species because of their rarity in the study area. Olive-sided Flycatcher observations used for test data were gathered from roadsides, though roads in this region are generally narrow and unpaved. Boreal Chickadee and Goldencrowned Kinglet are among the earliest breeding species of those studied. Our test data were restricted to late June when these species were not as detectable. In contrast, models for two additional early-breeding species, Ruby-crowned Kinglet and Dark-eyed Junco, performed well with late June test data.

Models for test species, Swainson's Thrush and Palm Warbler, agreed with the understanding of their breeding habitat in lowland coniferous forests. Palm Warbler were primarily found in stagnant black spruce and tamarack forests, which is consistent with our predictions and with many habitat descriptions (Niemi and Hanowski 1984, Warner and Wells 1984, Wilson 2013), although lower basal area was not included in any of our models (Wilson 2013). Swainson's Thrush was associated with mature cedar forests and not with black spruce or tamarack, which is consistent with other habitat descriptions (Warner and Wells 1984, Thompson et al. 1993, Mack and Yong 2000, Niemi et al. 2016). The high level of predictability of our modeling approach and the performance of models for these test species $(96 \%$ and $60 \%$ correctly predicted for Palm Warbler and Swainson's Thrush, respectively) support the use of this approach in determining species' habitat associations within lowland conifer forests of the ALS. 


\section{Individual species}

Yellow-bellied Flycatcher were found in the majority of stands and count locations and are likely breeding in most lowland conifer forest types in the ALS. The best model indicated this species preferentially selects stagnant stands surrounded by a variety of forest types. However, the model was not significant when compared with random models, suggesting this species is a generalist in the ALS and because of its ubiquity its habitat use is more difficult to predict. Other studies agree that Yellow-bellied Flycatcher is one of the most ubiquitous species among the conifer- and wetland-dominated habitats of the boreal (Erskine 1977, Gross and Lowther 2011). Currently, the ALS provides substantial forested habitat for this species; however, it did not occur in recently cut areas and would be negatively affected by extensive logging in the ALS.

Congeners Ruby-crowned Kinglet and Golden-crowned Kinglet used similar habitats, both preferring black spruce or cedar forests with upland forests in the broader landscape. These species appear to generally segregate on a gradient of productivity, with Rubycrowned Kinglet preferring more stagnant stands and Goldencrowned Kinglet more productive stands. However, these species were found in some of the same stands and might also segregate on smaller microhabitat scales or by foraging techniques not studied here (Franzreb 1984). Dark-eyed Junco were primarily associated with black spruce forests and, similar to Ruby-crowned Kinglet and Golden-crowned Kinglet, were not commonly found in pure tamarack forests. These associations largely agree with those in other portions of these species' breeding ranges (Erskine 1977, Swanson et al. 2008, Swanson et al. 2012). The protection of a productivity gradient of spruce forests and continued lack of harvesting in cedar will likely support continued breeding populations of these relatively common boreal species in the ALS.

\section{Species of Greatest Conservation Need}

Spruce Grouse, Black-backed Woodpecker, Olive-sided Flycatcher, Boreal Chickadee, and Connecticut Warbler are designated as Species of Greatest Conservation Need in Minnesota (SGCN; MNDNR 2016). Little is known about population trends of the first two species in Minnesota, but Connecticut Warbler and Olive-sided Flycatcher are of particular concern. Connecticut Warbler populations in Minnesota's National Forests have declined by as much as $7 \%$ per year over the past 21 years (Zlonis et al. 2014, Niemi et al. 2016) and both species are listed as conservation targets by various groups (Rich et al. 2004, Rosenberg et al. 2014, Environment Canada 2015). Despite this, only one study has completed a detailed analysis of Connecticut Warbler breeding habitat in Minnesota. In the Superior and Chippewa National forests, Lapin et al. (2013) found the Connecticut Warbler primarily in large contiguous patches of lowland conifer forests often surrounded by upland coniferous forest, as opposed to upland deciduous forest. Models with local stand variables (100 m buffer), including detailed measurements of forest stand characteristics such as tree and shrub density, performed poorly.

We found both the local (stand and $200 \mathrm{~m}$ buffer) and landscape (1000 $\mathrm{m}$ buffer) to be important for the breeding habitat of Connecticut Warbler in the ALS. Areas with highest predicted suitability were stagnant stands of intermediate basal area or productive stands of intermediate age (and thus basal area), surrounded by little or no productive cedar forest or sedge meadow. The latter negative associations imply selection for large areas of black spruce or tamarack, which is consistent with other habitat descriptions (Elder 1991, Pitocchelli et al. 2012, Lapin et al. 2013). Connecticut Warbler displayed a negative correlation with upland forests within $200 \mathrm{~m}$ (AUC $=0.59$, single variable model). This species would benefit from forest management that avoids harvesting black spruce-tamarack forests with intermediate basal area, especially in landscapes surrounded by additional black spruce-tamarack forests. Many of these forest stand types are at the cusp of being considered economically viable for harvest by forest managers and may have been extensively harvested in the past.

Despite low sample sizes, Olive-sided Flycatcher had a clear association with lowland conifer embedded within landscapes containing high proportions of nonforest. In this region, nonforest was primarily composed of cutover areas and shrubor sedge-dominated wetlands. These results are similar to findings regionally (Niemi et al. 2016) and in boreal Canada, indicating that preferred breeding habitat is usually open coniferous forests near wetlands or other open habitats (Haché et al. 2014, Environment Canada 2015). These habitats and landscapes are common in the ALS and much of the region is predicted as suitable breeding habitat. However, occupancy is low in the ALS, demonstrating the influence of other potential ecological or biological constraints. Several studies suggest that forest fires create suitable habitat for this species (Altman and Sallabanks 2012) and fire suppression has been identified as a significant threat to their populations (Environment Canada 2015). Fire suppression in conjunction with the naturally long fire rotations in lowland conifer communities (Aaseng et al. 2011) might be limiting Olive-sided Flycatcher populations in the ALS. Despite attracting breeding individuals, cutover areas and shrub- or sedgedominated wetlands might be acting as population sinks due to reduced reproductive success (Robertson and Hutto 2007).

Spruce Grouse, Black-backed Woodpecker, and Boreal Chickadee are permanent residents and some individuals may have completed breeding by the May sampling period. Individuals no longer defending territories or attempting to attract mates would have been more difficult to detect with aural surveys. For example, about half of the Boreal Chickadee presence samples were from sites in which they were not found on three previous visits. Still, presence-only models show selection of particular lowland conifer forests by these species.

Similarly to short-distance migrants, Spruce Grouse and Boreal Chickadee utilized black spruce and avoided tamarack forests. Previous research in Minnesota suggests that lowland spruce forests are particularly important for these species (Pietz and Tester 1982, Warner and Wells 1984). Spruce forests provide food resources and cover not available throughout the year in tamarack. In addition to shedding needles annually, tamarack does not retain seeds for the majority of the year (Duncan 1954). Protection of black spruce forests will likely allow the persistence of Boreal Chickadee, Spruce Grouse, and other archetypal boreal species in these hemiboreal forests of Minnesota. However, habitat needs of these permanent resident species likely vary throughout the year and other tree species associations could be important at certain times, e.g., Spruce Grouse use of tamarack during summer months in Wisconsin (Anich et al. 2013). 
Black-backed Woodpecker was the only species that responded to purely structural characteristics as opposed to tree species composition and landscape cover. This species was most associated with forest stands with large diameter trees. This association likely provides suitable habitat for nesting cavities and its preferred food, wood-boring beetles (Nappi et al. 2003, Tremblay et al. 2016). Black-backed Woodpeckers also benefit from forest fire (Nappi and Drapeau 2009), though with the long fire rotation period within many of the forests of the ALS, this species might instead select forests with large, mature trees that contain snags and downed logs (Tremblay et al. 2009). Fayt et al. (2005) and F. McKee (personal communication) suggest that Black-backed Woodpecker show similar responses to eastern larch beetle outbreaks as they do with other beetle outbreaks. However, increased harvest levels in black spruce and tamarack, as well as salvage logging after eastern larch beetle infestations, will likely reduce the size structure of lowland conifer forests in the ALS and availability of suitable Black-backed Woodpecker habitat.

\section{Conservation applications}

Maps represent a broad interpretation of the relative habitat suitability across the ALS landscape (Merow et al. 2013). These habitat suitability maps can be used for an individual species as well as for combinations of species based on their potential for co-occurrence. We developed thresholds for suitable and unsuitable habitat for five SGCN in Minnesota, which allowed us to combine species maps and provide managers with a useful conservation tool, indicating specific forest stands which may be of the highest conservation value for a suite of species. Managers have begun to use these results to designate potential conservation areas or special management units that are particularly significant for bird species breeding within the ALS. The low proportion of the ALS predicted to be suitable for four or more species shows the importance of using multiple species or assemblages when determining those conservation priorities (Moilanen et al. 2005).

The future of lowland conifers in this region is uncertain given the predicted declines in suitable habitat by the end of the century (Iverson et al. 2008, Galatowitsch et al. 2009, Handler et al. 2014). Black spruce, tamarack, and northern white-cedar are all predicted to decline in suitable habitat and biomass across northern Minnesota; declines in black spruce may be the most severe, which is especially of concern because most bird species included black spruce in their top models. These slow-growing lowland conifer species are particularly vulnerable to changing water levels and warmer temperatures (Handler et al. 2014). Additionally, insect outbreaks may become more frequent and intense as the climate changes and these species become stressed (Gray 2008). Eastern larch beetle has been increasing since 2001 (Handler et al. 2014) and there has since been mortality of at least 75,000 ha of tamarack in Minnesota (McKee and Aukema 2015). Declines of lowland conifer species will likely result in changes in habitat composition and widespread population declines in many of these lowland conifer-associated bird species (Niemi et al. 1998).

These lowland conifer forests also face increased pressures from logging. Since the 1980s, overall timber-harvest rates in Minnesota have stayed stable or slightly decreased, while over the same period, annual harvest of black spruce and tamarack has more than doubled (MNDNR 2013). Increased logging of lowland conifers not only results in the loss of mature forest, but also the fragmentation of large tracts of forest that historically had long intervals between stand replacing disturbances (7001000 years; Aaseng et al. 2011). Based on the results of our study, these changes are likely to affect many species, including those responding to availability of lowland conifer at broad spatial scales as well as those using mature and productive stands. For example, both Lapin et al. (2013) and this study showed the Connecticut Warbler prefer larger, contiguous tracts of black spruce/tamarack that will become increasingly uncommon if harvest rates continue to rise.

Results from this study can facilitate conservation and forest management practices in an important forest type in Minnesota and throughout the boreal by maximizing the chance that breeding bird species utilizing lowland conifer forests will retain suitable habitat in the future. Though climate change will impact these lowland conifer ecosystems, adaptive forest management has the potential to mitigate some of these effects by increasing resistance and adaptive capacity (Duveneck et al. 2014). The maps of suitable habitat of these lowland conifer-associated bird species will help prioritize locations in which management may have the most impact. Additionally, the methodological approach we developed could be useful in many landscape or regional-scale conservation applications, especially when target species are understudied but when conservation action must be implemented promptly.

Threats to birds are well documented and the most imperiled species have been identified (Rosenberg et al. 2014), but declines in populations are unlikely to be reversed unless conservation actions are taken at the appropriate scale. Our study indicated that a narrow geographical scope and habitat breadth can be used to identify specific habitat associations that can facilitate local and regional conservation actions. These results should be cautiously applied to other geographic areas (Townsend Peterson et al. 2007). However, we recommend that future research and management collaborations develop similar conservation targets at regional scales because of changing habitat associations and unique environmental conditions.

Responses to this article can be read online at: http://www.ace-eco.org/issues/responses.php/954

\section{Acknowledgments:}

This study was funded by the MNDNR and the USFWS through State Wildlife Grant, T-39-R-1/ F12AF00328. We would like to thank Edward Keyel for assistance with field work and Gretchen Mehmel for support throughout data collection and analysis.

\section{LITERATURE CITED}

Aaseng, N. E., J. C. Almendinger, R. P. Dana, D. S. Hanson, M. D. Lee, E. R. Rowe, K. A. Rusterholz, and D. S. Wovcha. 2011. Minnesota's native plant community classification: a statewide classification of terrestrial and wetland vegetation based on numerical analysis of plot data. Biological Report No. 108. 
Minnesota County Biological Survey, Ecological Land Classification Program, and Natural Heritage and Nongame Research Program. Minnesota Department of Natural Resources, St. Paul, Minnesota, USA.

Altman, B., and R. Sallabanks. 2012. Olive-sided Flycatcher (Contopus cooperi). In P. G. Rodewald, editor. The birds of North America. Cornell Lab of Ornithology, Ithaca, New York, USA. http://dx.doi.org/10.2173/bna.502

Anich, N. M., M. Worland, and K. J. Martin. 2013. Habitat use by spruce grouse in northern Wisconsin. Wildlife Society Bulletin 37:766-777. http://dx.doi.org/10.1002/wsb.318

Araújo, M. B., R. G. Pearson, W. Thuiller, and M. Erhard. 2005. Validation of species-climate impact models under climate change. Global Change Biology 11:1504-1513. http://dx.doi. org/10.1111/j.1365-2486.2005.01000.x

Bellamy, C., C. Scott, and J. Altringham. 2013. Multiscale, presence-only habitat suitability models: fine-resolution maps for eight bat species. Journal of Applied Ecology 50:892-901. http:// dx.doi.org/10.1111/1365-2664.12117

Beyer, H. L. 2012. Geospatial modelling environment (Version 0.7.3.0). [online] URL: http://www.spatialecology.com/

Crozier, G. E, and G. J. Niemi. 2003. Using patch and landscape variables to model bird abundance in a naturally heterogeneous landscape. Canadian Journal of Zoology 81:441-452. http://dx. doi.org/10.1139/z03-022

Dawson, D. K. 1979. Bird communities associated with succession and management of lowland conifer forests. Pages 120-131 in Management of north central and northeastern forests for nongame birds: workshop proceedings. U.S. Forest Service, North Central Forest Experiment Station, St. Paul, Minnesota, USA

Drolet, B., A. Desrochers, and M. J. Fortin. 1999. Effects of landscape structure on nesting songbird distribution in a harvested boreal forest. Condor 101:699-704. http://dx.doi. org/10.2307/1370205

Dufrêne, M., and P. Legendre. 1997. Species assemblages and indicator species: the need for a flexible asymmetrical approach. Ecological Monographs 67:345-366. http://dx.doi.org/10.2307/2963459

Duncan, D. P. 1954. A study of some of the factors affecting the natural regeneration of tamarack (Larix laricina) in Minnesota. Ecology 35:498-521. http://dx.doi.org/10.2307/1931040

Duveneck, M. J., R. M. Scheller, and M. A. White. 2014. Effects of alternative forest management on biomass and species diversity in the face of climate change in the northern Great Lakes region (USA). Canadian Journal of Forestry Resources 44:700-710. http://dx.doi.org/10.1139/cjfr-2013-0391

Elder, D. H. 1991. Breeding habitat of the Connecticut Warbler in the Rainy River District. Ontario Birds 9:84-86.

Elith, J., C. H. Graham, R. P. Anderson, M. Dudík, S. Ferrier, A. Guisan, R. J. Hijmans, F. Huettmann, J. R. Leathwick, A. Lehmann, J. Li, L. G. Lohmann, B. A. Loiselle, G. Manion, C. Moritz, M. Nakamura, Y. Nakazawa, J. M. Overton, A. Townsend Peterson, S. J. Phillips, K. Richardson, R. Scachetti-
Pereira, R. E. Shapire, J. Soberón, S. Williams, M. S. Wisz, and N. E. Zimmermann. 2006. Novel methods improve prediction of species' distributions from occurrence data. Ecography 29:129-151. http://dx.doi.org/10.1111/j.2006.0906-7590.04596.x

Elith, J., S. J. Phillips, T. Hastie, M. Dudík, Y. E. Chee, and C. J. Yates. 2011. A statistical explanation of MaxEnt for ecologists. Diversity and Distributions 17:43-57. http://dx.doi.org/10.1111/ j.1472-4642.2010.00725.x

Environment Canada. 2015. Recovery strategy for Olive-sided Flycatcher (Contopus cooperi) in Canada [Proposed]. Species at Risk Act Recovery Strategy Series. Environment Canada, Ottawa, Ontario, Canada.

Erskine, A. J. 1977. Birds in boreal Canada: communities, densities and adaptations. Canadian Wildlife Service report series No. 41. Minister of Supply and Services, Ottawa, Ontario, Canada.

Etterson, M. A., G. J. Niemi, and N. P. Danz. 2009. Estimating the effects of detection heterogeneity and overdispersion on trends estimated from avian point counts. Ecological Applications 19:2049-2066. http://dx.doi.org/10.1890/08-1317.1

Fayt, P., M. M. Machmer, and C. Steeger. 2005. Regulation of spruce bark beetles by woodpeckers: a literature review. Forest Ecology and Management 206:1-14. http://dx.doi.org/10.1016/j. foreco.2004.10.054

Franklin, J. 2010. Mapping species distributions: spatial inference and prediction. Cambridge University Press, Cambridge, UK. http://dx.doi.org/10.1017/cbo9780511810602

Franzreb, K. E. 1984. Foraging habits of Ruby-crowned and Golden-crowned Kinglets in an Arizona montane forest. Condor 86:139-145. http://dx.doi.org/10.2307/1367027

Galatowitsch, S., L. Frelich, and L. Phillips-Mao. 2009. Regional climate change adaptation strategies for biodiversity conservation in a midcontinental region of North America. Biological Conservation 142:2012-2022. http://dx.doi.org/10.1016/j.

biocon.2009.03.030

Gray, D. R. 2008. The relationship between climate and outbreak characteristics of the spruce budworm in eastern Canada. Climate Change 87:361-383. http://dx.doi.org/10.1007/s10584-007-9317-5

Grigal, D. F., C. G. Buttleman, and L. K. Kernik. 1985. Biomass and productivity of the woody strata of forested bogs in northern Minnesota. Canadian Journal of Botany 63:2416-2424. http://dx. doi.org/10.1139/b85-345

Gross, D. A., and P. E. Lowther. 2011. Yellow-bellied Flycatcher (Empidonax flaviventris). In P. G. Rodewald, editor. The birds of North America. Cornell Lab of Ornithology, Ithaca, New York, USA. http://dx.doi.org/10.2173/bna.566

Haché, S., P. Solymos, T. Fontaine, E. M. Bayne, S. G. Cumming, F. K. A Schmiegelow, and D. Stralberg. 2014. Critical habitat of Olive-sided Flycatcher, Canada Warbler, and Common Nighthawk in Canada (Project K4B20-13-0367). Technical report for Environment Canada, Ottawa, Ontario, Canada.

Hackett, R. L., and R. A. Dahlman. 1997. Minnesota timber industry-an assessment of timber product output and use, 1992. Resource Bulletin NC-186. U.S. Forest Service, North Central Forest Experiment Station, St. Paul, Minnesota, USA. 
Handler, S., M. J. Duveneck, L. Iverson, E. Peters, R. M. Scheller, K. R. Wythers, L. Brandt, P. Butler, M. Janowiak, P. D. Shannon, C. Swanston, K. Barrett, R. Kolka, C. McQuiston, B. Palik, P. B. Reich, C. Turner, M. White, C. Adams, A. D'Amato, S. Hagell, P. Johnson, R. Johnson, M. Larson, S. Matthews, R. Montgomery, S. Olson, M. Peters, A. Prasad, J. Rajala, J. Daley, M. Davenport, M. R. Emery, D. Fehringer, C. L. Hoving, G. Johnson, L. Johnson, D. Neitzel, A. Rissman, C. Rittenhouse, and R. Ziel. 2014. Minnesota forest ecosystem vulnerability assessment and synthesis: a report from the Northwoods Climate Change Response Framework Project. General Technical Report NRS-133. U.S. Forest Service, Northern Research Station, Newtown Square, Pennsylvania, USA. http://dx.doi.org/10.2737/ nrs-gtr-133

Hanowski, J. M., and G. J. Niemi. 1995. Experimental design considerations for establishing an off-road, habitat specific bird monitoring program using point counts. Monitoring bird populations by point counts. General Technical Report PSWGTR-149. U.S. Forest Service, Pacific Southwest Research Station, Albany, California, USA.

Hansen, M. C., P. V. Potapov, R. Moore, M. Hancher, S. A. Turubanova, A. Tyukavina, D. Thau, S. V. Stehman, S. J. Goetz, T. R. Loveland, A. Kommareddy, A. Egorov, L. Chini, C. O. Justice, and J. R. G. Townshend. 2013. High-resolution global maps of 21st-century forest cover change. Science 342:850-853. http://dx.doi.org/10.1126/science.1244693

Hawrot, R. Y., and G. J. Niemi. 1996. Effects of edge type and patch shape on avian communities in a mixed conifer-hardwood forest. Auk 113: 586-598. http://dx.doi.org/10.2307/4088979

Heinselman, M. L. 1981. Fire and succession in the conifer forests of northern North America. Pages 374-405 in D. C. West, H. H. Shugart, and D. B. Botkin, editors. Forest succession: concepts and application. Springer, New York, New York, USA. http://dx. doi.org/10.1007/978-1-4612-5950-3_23

Hobson, K. A., and E. Bayne. 2000. Breeding bird communities in boreal forest of western Canada: consequences of "unmixing" the mixedwoods. Condor 102:759-769. http://dx.doi.org/10.2307/1370303

Imbeau, L., J.-P. L. Savard, and R. Gagnon. 1999. Comparing bird assemblages in successional black spruce stands originating from fire and logging. Canadian Journal of Zoology 77:1850-1860. http://dx.doi.org/10.1139/z99-172

Imbeau, L., M.-H. St-Laurent, L. Marzell, and V. Brodeur. 2015. Current capacity to conduct ecologically sustainable forest management in northeastern Canada reveals challenges for conservation of biodiversity. Canadian Journal of Forest Research 45:567-578. http://dx.doi.org/10.1139/cjfr-2014-0123

Iverson, L. R., A. M. Prasad, S. N. Matthews, and M. Peters. 2008. Estimating potential habitat for 134 eastern U.S. tree species under six climate scenarios. Forest Ecology and Management 254:390-406. [online] URL: http://www.treesearch.fs.fed.us/ pubs/1341 http://dx.doi.org/10.1016/j.foreco.2007.07.023

Jackson, M. M., S. E. Gergel, and K. Martin. 2015. Citizen science and field survey observations provide comparable results for mapping Vancouver Island White-tailed Ptarmigan (Lagopus leucura saxatilis) distributions. Biological Conservation 181:162-172. http://dx.doi.org/10.1016/j.biocon.2014.11.010
Johnston, M. 2009. Vulnerability of Canada's tree species to climate change and management options for adaptation: an overview for policy makers and practitioners. Canadian Council of Forest Ministers, Ottawa, Ontario, Canada.

Keller, J. K., and C. R. Smith. 2014. Improving GIS-based wildlifehabitat analysis. Springer, Heidelberg, Germany. http://dx.doi. org/10.1007/978-3-319-09608-7

Lapin, C. N., M. A. Etterson, and G. J. Niemi. 2013. Occurrence of the Connecticut Warbler increases with size of patches of coniferous forest. Condor 115:168-117. http://dx.doi.org/10.1525/ cond.2013.110202

Larsen, J. A. 1982. Ecology of the northern lowland bogs and conifer forests. Academic Press, New York, New York, USA.

Mack, D. E. and W. Yong. 2000. Swainson's Thrush (Catharus ustulatus). In P. G. Rodewald, editor. The birds of North America. Cornell Lab of Ornithology, Ithaca, New York, USA. http://dx. doi.org/10.2173/bna.540

McCune, B., M. J. Mefford. 2006. PC-ORD. Multivariate analysis of ecological data. Version 5. MjM Software, Gleneden Beach, Oregon, USA.

McGarigal, K., S. A. Cushman, and E. Ene. 2012. FRAGSTATS v4: Spatial pattern analysis program for categorical and continuous maps. University of Massachusetts, Amherst, Massachusetts, USA. [online] URL: http://www.umass.edu/landeco/research/ fragstats/fragstats.html

McKee, F. R., and B. H. Aukema. 2015. Influence of temperature on the reproductive success, brood development and brood fitness of the eastern larch beetle Dendroctonus simplex LeConte. Agricultural and Forest Entomology 17:102-112. http://dx.doi. org/10.1111/afe.12087

Merow C., and J. A. Silander Jr. 2014. A comparison of Maxlike and MaxEnt for modelling species distributions. Methods in Ecology and Evolution 5:215-225. http://dx.doi.org/10.1111/2041-210x.12152

Merow C., M. J. Smith, and J. A. Silander Jr. 2013. A practical guide to MaxEnt for modeling species' distributions: what it does, and why inputs and settings matter. Ecography 36:1058-1069. http://dx.doi.org/10.1111/j.1600-0587.2013.07872.x

Minnesota Department of Natural Resources (MNDNR). 1984. Recommendations for the protection of ecologically significant peatlands in Minnesota. Minnesota Department of Natural Resources, St. Paul, Minnesota, USA.

Minnesota Department of Natural Resources (MNDNR). 2012. The DNR data deli. Minnesota Department of Natural Resources, St. Paul, Minnesota, USA. [online] URL: http://deli. dnr.state.mn.us/

Minnesota Department of Natural Resources (MNDNR). 2013. Minnesota's forest resources 2013. Minnesota Department of Natural Resources, St. Paul, Minnesota, USA. [online] URL: http://files.dnr.state.mn.us/forestry/um/forestresourcesreport_13. pdf

Minnesota Department of Natural Resources (MNDNR). 2016. Minnesota's wildlife action plan 2015-2025. Division of Ecological 
and Water Resources, Minnesota Department of Natural Resources, St. Paul, Minnesota, USA.

Moilanen, A., A. M. A. Franco, R. I. Early, R. Fox, B. Wintle, and C. D. Thomas. 2005. Prioritizing multiple-use landscapes for conservation: methods for large multi-species planning problems. Proceedings Royal Society B: Biological Sciences 272:1885-1891. http://dx.doi.org/10.1098/rspb.2005.3164

Nappi, A., and P. Drapeau. 2009. Reproductive success of the Black-backed Woodpecker (Picoides arcticus) in burned boreal forests: Are burns source habitats? Biological Conservation 142:1381-1391. http://dx.doi.org/10.1016/j.biocon.2009.01.022

Nappi, A., P. Drapeau, J.-F. Giroux, and J.-P. L Savard. 2003. Snag use by foraging Black-backed Woodpeckers (Picoides arcticus) in a recently burned eastern boreal forest. Auk 120:505-511. http://dx.doi.org/10.1642/0004-8038(2003)120[0505: SUBFBW]2.0.CO;2

Niemi, G. J., and J. M. Hanowski. 1984. Effects of a transmission line on bird populations in the Red Lake Peatland, northern Minnesota. Auk 101:487-498.

Niemi, G. J., J. Hanowski, R. Helle, R. Howe, M. Mönkkönen, L. A. Venier, and D. Welsh 1998. Ecological sustainability of birds in boreal forests. Conservation Ecology 2(2):17. http://dx.doi. org/10.5751/ES-00079-020217

Niemi, G. J., R. W. Howe, B. R. Sturtevant, L. R. Parker, A. R. Grinde, N. P. Danz, M. Nelson, E. J. Zlonis, N. G. Walton, E. E. Geise, and S. M. Lietz. 2016. Analysis of long-term forest bird monitoring data from national forests of the western Great Lakes Region. General Technical Report NRS-159. U.S. Forest Service, Northern Research Station, Newtown Square, Pennsylvania, USA.

Parolo, G., G. Rossi, and A. Ferrarini. 2008. Toward improved species niche modelling: Arnica montana in the Alps as a case study. Journal of Applied Ecology 45:1410-1418. http://dx.doi. org/10.1111/j.1365-2664.2008.01516.x

Pietz, P. J., and J. R. Tester. 1982. Habitat selection by sympatric spruce and Ruffed Grouse in north central Minnesota. Journal of Wildlife Management 46:391-403. http://dx.doi.org/10.2307/3808651

Phillips, S. J., R. P. Anderson, and R. E. Schapire. 2006. Maximum entropy modeling of species geographic distributions. Ecological Modelling 190:231-259. http://dx.doi.org/10.1016/j.ecolmodel.2005.03.026

Phillips, S. J., and M. Dudík. 2008. Modeling of species distributions with MaxEnt: new extensions and a comprehensive evaluation. Ecography 31:161-175. http://dx.doi.org/10.1111/ j.0906-7590.2008.5203.x

Phillips, S. J., M. Dudík, J. Elith, C. H. Graham, A. Lehmann, J. Leathwick, and S. Ferrier. 2009. Sample selection bias and presence-only distribution models: implications for background and pseudo-absence data. Ecological Applications 19:181-197. http://dx.doi.org/10.1890/07-2153.1

Pitocchelli, J., J. Jones, D. Jones, and J. Bouchie. 2012. Connecticut Warbler (Oporornis agilis). In P. G. Rodewald, editor. The birds of North America. Cornell Lab of Ornithology, Ithaca, New York, USA. http://dx.doi.org/10.2173/bna.320
Raes, N, and H. ter Steege. 2007. A null-model for significance testing of presence-only species distribution models. Ecography 30:727-736. http://dx.doi.org/10.1111/j.2007.0906-7590.05041.x

Ralston, J., D. I. King, W. V. DeLuca, G. J. Niemi, M. J. Glennon, J. C. Scarl, and J. D. Lambert. 2015. Analysis of combined data sets yields trend estimates for vulnerable spruce-fir birds in northern United States. Biological Conservation 187:270-278. http://dx.doi.org/10.1016/j.biocon.2015.04.029

Renner, I. W., and D. I. Warton. 2013. Equivalence of MAXENT and Poisson point process models for species distribution modeling in ecology. Biometrics 69:274-281. http://dx.doi. org/10.1111/j.1541-0420.2012.01824.x

Rich, T. D., C. J. Beardmore, H. Berlanga, P. J. Blancher, M. S. W. Bradstreet, G. S. Butcher, and T. Will. 2004. Partners in Flight North American landbird conservation plan. Partners in Flight, Ithaca, New York, USA.

Robertson, B. A., and R. L. Hutto. 2007. Is selectively harvested forest an ecological trap for Olive-sided Flycatchers? Condor 109:109-121. http://dx.doi.org/10.1650/0010-5422(2007)109[109: ISHFAE]2.0.CO;2

Robinson, W. L. 1969. Habitat selection by spruce grouse in northern Michigan. Journal of Wildlife Management 33:113-120. http://dx.doi.org/10.2307/3799657

Rosenberg, K. V., D. Pashley, B. Andres, P. J. Blancher, G. S. Butcher, W. C. Hunter, D. Mehlman, A. O. Panjabi, M. Parr, G. Wallace, and D. Wiedenfeld. 2014. The state of the birds 2014 watch list. North American Bird Conservation Initiative, U.S. Committee. Washington, D.C., USA.

Royle, J. A., R. B. Chandler, C. Yackulic, and J. D. Nichols. 2012. Likelihood analysis of species occurrence probability from presence-only data for modelling species distributions. Methods in Ecology and Evolution 3:545-554. http://dx.doi.org/10.1111/ j.2041-210X.2011.00182.x

Schmiegelow, F. K. A., D. P. Stepnisky, C. A. Stambaugh, and M. Koivula. 2006. Reconciling salvage logging of boreal forests with a natural-disturbance management model. Conservation Biology 20:971-983. http://dx.doi.org/10.1111/j.1523-1739.2006.00496.x

Shugart, H. H., R. Leemans, and G. B. Bonan, editors. 1992. A systems analysis of the global boreal forest. Cambridge University Press, Cambridge, UK. http://dx.doi.org/10.1017/cbo9780511565489

Soja, A. J., N. M. Tchebakova, N. H. French, M. D. Flannigan, H. H. Shugart, B. J. Stocks, A. I. Sukhinin, E. I. Parfenova, F. S. Chapin III, and P. W. Stackhouse Jr. 2007. Climate-induced boreal forest change: predictions versus current observations. Global and Planetary Change 56:274-296. http://dx.doi.org/10.1016/j. gloplacha.2006.07.028

Støa, B. 2014. Exploring the value of museum data for use in species distribution modeling: data limitations and how to tackle them. Dissertation. University of Oslo, Oslo, Norway. https://www.duo. uio.no/bitstream/handle/10852/40492/PhD-Stoa-DUO.pdf? sequence $=1 \&$ isAllowed $=\mathrm{y}$

Stralberg, D., S. M. Matsuoka, A. Hamann, E. M. Bayne, P. Sólymos, F. K. A. Schmiegelow, X. Wang, S. G. Cumming, and S. J. Song. 2015. Projecting boreal bird responses to climate 
change: the signal exceeds the noise. Ecological Applications 25:52-69. http://dx.doi.org/10.1890/13-2289.1

Swanson, D. L., J. L. Ingold, and R. Galati. 2012. Goldencrowned Kinglet (Regulus satrapa). In P. G. Rodewald, editor. The birds of North America. Cornell Lab of Ornithology, Ithaca, New York, USA. http://dx.doi.org/10.2173/bna.301

Swanson, D. L., J. L. Ingold, and G. E. Wallace. 2008. Rubycrowned Kinglet (Regulus calendula). In P. G. Rodewald, editor. The birds of North America. Cornell Lab of Ornithology, Ithaca, New York, USA. http://dx.doi.org/10.2173/bna.119

Thompson, F. R., S. J. Lewis, J. Green, and D. Ewert. 1993. Status of neotropical migrant landbirds in the Midwest: identifying species of management concern. Pages 145-158 in D. M. Finch and P. W. Stangel, editors. Status and management of neotropical migratory birds. General Technical Report RM-229. U.S. Forest Service, Rocky Mountain Forest and Range Experiment Station, Fort Collins, Colorado, USA.

Townsend Peterson, A., M. Papeş, and M. Eaton. 2007. Transferability and model evaluation in ecological niche modeling: a comparison of GARP and MaxEnt. Ecography 30:550-560. http://dx.doi.org/10.1111/j.0906-7590.2007.05102.x

Tremblay, J. A., R. D. Dixon, V. A. Saab, P. Pyle and M. A. Patten. 2016. Black-backed Woodpecker (Picoides arcticus). In P. G. Rodewald, editor. The birds of North America. Cornell Lab of Ornithology, Ithaca, New York, USA. http://dx.doi.org/10.2173/ bna.509

Tremblay, J. A., C. Ibarzabal, C. Dussault, and J.-P. L. Savard. 2009. Habitat requirements of breeding Black-backed Woodpecker in unburned boreal forests. Avian Conservation and Ecology - Écologie et conservation des oiseaux 4(1):2. http://dx. doi.org/10.5751/ACE-00297-040102

van Proosdij, A. S. J., M. S. M. Sosef, J. J. Wieringa, and N. Raes. 2016. Minimum required number of specimen records to develop accurate species distribution models. Ecography 39:542-552. http://dx.doi.org/10.1111/ecog.01509

Warner, D., and D. Wells 1984. Bird population structure and seasonal habitat use as indicators of environmental quality of peatlands. Minnesota Department of Natural Resources, St. Paul, Minnesota, USA.

Warren, D. L., R. E. Glor, and M. Turelli. 2008. Environmental niche equivalency versus conservatism: quantitative approaches to niche evolution. Evolution 62:2868-2883. http://dx.doi. org/10.1111/j.1558-5646.2008.00482.x

Warren, D. L., R. E. Glor, and M. Turelli. 2010. ENMTools: a toolbox for comparative studies of environmental niche models. Ecography 33:607-611. http://dx.doi.org/10.1111/j.1600-0587.2009.06142.

$\mathrm{x}$

Editor-in-Chief: Ryan Norris Subject Editor: Philip D.Taylor
Warren, D. L., and S. N. Seifert. 2011. Ecological niche modeling in Maxent: the importance of model complexity and the performance of model selection criteria. Ecological Applications 21:335-342. http://dx.doi.org/10.1890/10-1171.1

Warren, T. L., M. G. Betts, A. W. Diamond, and G. J. Forbes. 2005. The influence of local habitat and landscape composition on cavity-nesting birds in a forested mosaic. Forest Ecology and Management 214:331-343. http://dx.doi.org/10.1016/j.foreco.2005.04.017

Wilson, W. H. 2013. Palm Warbler (Dendroica palmarum). In P. G. Rodewald, editor. The birds of North America. Cornell Lab of Ornithology, Ithaca, New York, USA. http://dx.doi.org/10.2173/ bna. 238

Zlonis, E. J., A. Grinde, E. Condon, H. Panci, Y. Li, R. R. Regal, and G. J. Niemi. 2014. Summary of breeding bird trends in the Chippewa and Superior National Forests of Minnesota 1995-2014. NRRI technical report NRRI/TR-2014/44, University of Minnesota Duluth, USA.
Sponsored by the Society of Canadian Ornithologists and Bird Studies Canada Parrainée par la Société des ornithologistes $d u$ Canada et Études d'oiseaux Canada

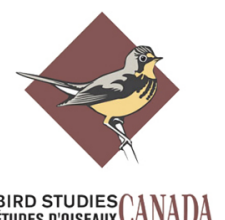

